\title{
Recessions and Mortality in Spain, 1980-1997
}

\author{
JOSÉ A. TAPIA GRANADOS \\ Institute of Labor and Industrial Relations and School of Social Work, University of Michigan, \\ 1111 East Catherine Street, Room 308, Ann Arbor, MI 48109-2054, USA \\ (e-mail: jatapia@umich.edu)
}

Received 7 May 2004; accepted 20 April 2005

Tapia Granados, J.A., 2005, Recessions and Mortality in Spain, 1980-1997, European Journal of Population, 21: 393-422.

\begin{abstract}
The relationship between economic fluctuations and mortality is assessed with data from Spain during the years 1980-1997, when national unemployment oscillated between 7\% and $24 \%$. Mortality rates of the Spanish provinces are modeled in fixed-effect panel regressions as functions of the demographic structure and the economic conditions. Unemployment effects on general mortality, sex-specific mortality, and mortality for major causes of death are negative, i.e., death rates increase procyclically when joblessness diminishes in an economic expansion. Homicides and female suicides are only weakly related or unrelated to economic fluctuations, but male suicides escalate countercyclically during economic downturns.
\end{abstract}

Key words: business cycles, death rates, mortality, recessions, Spain

Tapia Granados, J.A., 2005, Récession et mortalité en Espagne, 1980-1997, Revue Européenne de Démographie, 21: 393-422.

Résumé. L'article s'intéresse aux relations entre fluctuations économiques et mortalité en Espagne sur la période 1980-1997, au cours de laquelle le taux de chômage a oscillé entre 7 et $24 \%$. Un modèle de régression à effets constants sur données de panel est appliqué aux taux de mortalité par provinces espagnoles, prenant en compte la structure démographique et les conditions économiques. Le chômage a un effet négatif sur la mortalité totale, la mortalité par sexe et les principales causes de décès. Autrement dit, les taux de mortalité augmentent quand, en phase d'expansion économique, le chômage diminue. Les homicides et les suicides féminins sont faiblement ou pas du tout liés aux fluctuations économiques alors que les suicides masculins augmentent lorsque la situation économique se détériore.

Mots clés: cycles d'activité économique, taux de mortalité, mortalité, récession, Espagne

\section{Introduction}

In the 1920s, William Ogburn and Dorothy Thomas found that economic expansions were associated with increases in mortality in the United 
States and in Great Britain. This association never received much attention, probably due to its counterintuitive nature, in spite of being reported again half a century later by Eyer (1977a), Higgs (1979), and Graham et al. (1992) with US data, and by Adams (1981) with Canadian data (discussed in Jin et al., 1995).

In a series of studies published from the 1970s onward, Brenner (1971, 1976, 1980, 1993, 1995) attempted to demonstrate lagged effects of the economy on mortality, and argued that increases in mortality were produced by recessions occurring years earlier. These studies have generated controversy over decades. Results from Hexter (1925), Bunn (1979, 1980), Watkins (1985), McAvinchey (1984), Junankar (1991), and Catalano (1997) apparently supported Brenner's argument to some extent. Contrarily, Lew (1979), Goff (1980), Winter (1983), Forbes and McGregor (1984), LaPlante (1985), and Kagan (1987) tended to dismiss the evidence of any relationship between business cycles and mortality. Despite serious criticisms of Brenner's findings and methods (Eyer, 1976a, b; Kasl, 1979; Gravelle et al., 1981; Wagstaff, 1985; Cook, 1986; Søgaard, 1992), the hypothesis of lagged effects of recessions on mortality was often cited as confirmed during the 1990s, perhaps because it fits with the common perception that economic slumps must be bad for health. In the Malthusian framework that is common in historical demography, drops in the standard of living associate with upturns in mortality and, indeed, studies of historical mortality series in pre-industrial settings have shown death rate upswings closely following bad harvests (Thomas, 1941), or extreme hikes in wheat prices (Schofield, 1983). In European pre-industrial economies, Galloway (1988) found that hikes in mortality as a response to increases in grain prices become more muted as the level of development advanced. It would therefore be expected that mortality responses to income changes drop as time goes. According to Lee (1997: 1083), however, the income elasticity of mortality is -0.20 for Latin American countries during the recent decades of structural adjustment, and only -0.15 for European pre-industrial economies. In the opinion of this author the empirical literature shows that both in pre-1900 European nations and in contemporary countries of the Third World periods of economic hardship augment mortality in the short run, i.e., that mortality responses are countercyclical both in historical pre-industrial data and in contemporary low-income countries (Lee, 1997:1108).

In 2000, Ruhm used a statistical technique - panel regressions - never before applied to study the short-term impact of the economy on mortality. Analyzing data from the fifty states of the United States, he found that death rates due to major causes of death drop when unemployment increases in an economic downturn. These results from the United States have been replicated with panel data of the German Länder in 1980-2000 by Neumayer 
(2004a, b), and with a panel of OECD countries in the years 1960-1997 by Gerdtham and Ruhm (2002). In a study of Finland in 1987-1995, when unemployment escalated from $5.0 \%$ to $17.1 \%$, Jäntti et al. (2000: 358) found also that "contrary to expectations, the development of life expectancy and mortality was more favorable during the recession than during economic prosperity," though the effects of the economy on mortality were considered not statistically significant when estimated in a fixed-effects model.

This paper addresses the relationship between short-term variations in mortality and short-term fluctuations of the Spanish economy during the years 1980-1997. Spain has important differences from countries like the United States or Germany - for instance, a lower income level, and the highest unemployment among the Western industrial countries in the last decades of the $20^{\text {th }}$ century. The oscillation of joblessness in a range between $7 \%$ and $24 \%$ during the period of study provides a "natural experiment" in which to test the relationship between macroeconomic "cycles" and death rates. The empirical question was to decide if, in this particular sample, mortality was or was not associated with the fluctuations of the economy, and if so, in what direction. To this effect panel regressions were used. The method used by Ruhm (2000) with the states of the United States is applied here to the fifty Spanish provinces. It was also expanded in several ways. Sex-specific mortality rates and sex-specific economic indicators were analyzed, and panel regressions were applied not only to levels of death rates, but also to differences in death rates. The results indicate that mortality in the Spanish provinces decreases when unemployment grows, i.e., moving procyclically in the same way found by Ruhm in the United States and Neumayer in Germany.

\section{Pathways for a Procyclical Oscillation of Mortality}

Eyer was probably the first to present a comprehensive theory to explain the increase in mortality associated with economic expansions (Eyer, 1977b, 1984; Eyer and Sterling, 1977; Sterling and Eyer, 1981). His basic notion was that during economic expansions there is a general increase in stress levels, a subsequent decrease in immunity, and an increase in the risk of injury. Intermediate links in these pathways might be increased levels of work hours and work pace, consumption of noxious substances, reduced sleep, and weakening of social support because of migration and decrease in leisure time. The stress-immunity effect may also be compounded by procyclical changes in both indoor and outdoor air pollution and by the increasing frequency of high-risk behaviors such as smoking, driving, and excessive drinking during economic upturns. Through these pathways (Figure 1) business expansions would not only increase the risk of death of previously healthy people, but would also promote deaths among persons with 


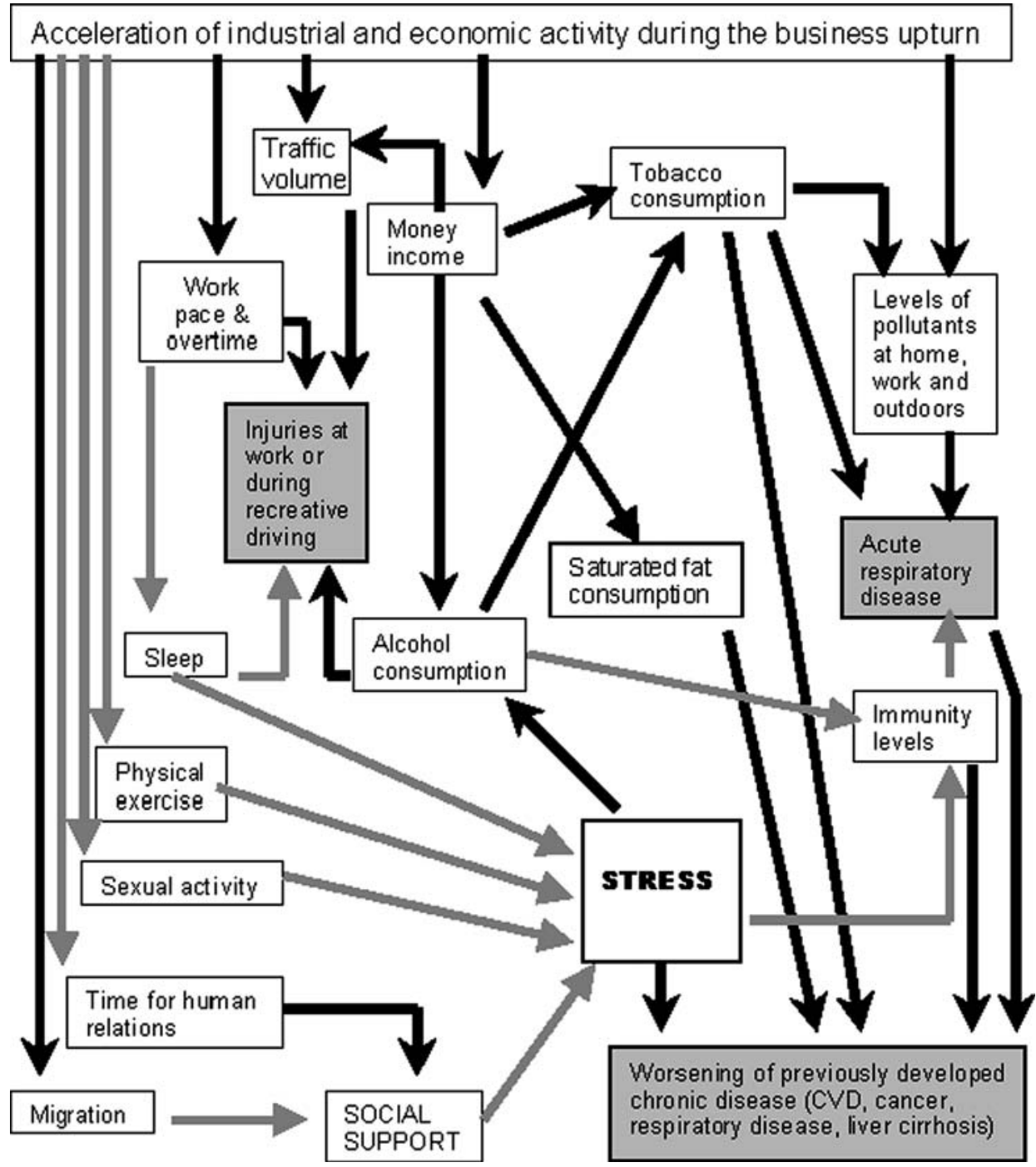

Figure 1. Causal pathways in a stress-mediated model of procyclical mortality. Black thick arrows and thin gray arrows represent positive (direct) and negative (inverse) effects, respectively. For instance, a business upturn increases work pace and overtime which in turn tend to reduce sleep, which raises both injury risk and stress levels. For many of these pathways (most of which, but not all, were proposed by Eyer in the 1970s) there is strong empirical evidence. The three shaded rectangles represent the final steps leading to death. Many other possible links (e.g., stress increasing tobacco consumption, physical exercise directly improving immunity or decreasing factors for heart disease) and bi-directional pathways (alcohol consumption increasing tobacco consumption and vice versa) have to be omitted to simplify the scheme. 
underlying chronic disease. Several of these pathways are discussed in more detail below.

The increased risk of disease, injury, or death associated with job stress and fatigue was studied as early as 1914 by Hobson (1914: 67-71). A relationship between work stress and health, including psychological and cardiovascular disorders and deaths, has been repeatedly documented (Kalimo et al., 1987; Graertz, 1993; Sparks et al., 1997; Schnall et al., 2000; Lundberg and Hellström, 2002). In Karasek and Theorell's demand-control model, high job demands associated with low control generate high risk of mortality, particularly due to cardiovascular disease (Peterson, 1994; Bloomberg et al., 1994; Johnson and Hall, 1995; Marmot and Feeney, 1996). In Japan the popular notion of karoshi or death from overwork has been supported by data (Sokejima and Kagamimori, 1998). Overwork, work strain and effort intensity are clearly linked to business fluctuations, since during economic upturns, firms try to cope with the increased demand in the short term by raising the rate of work and demanding overtime from the employees. Occupational injuries, which may result from increased work strain or increased volume or pace of work, also show a procyclical fluctuation (Kossoris, 1938; Arno, 1984; Robinson, 1988; Robinson and Shor, 1989). In the booming American economy of the year 2000, some state legislatures tried to pass bills establishing caps for overtime (which is mandatory for U.S. employees when requested by employers) to prevent scandalous increases in job injuries and deaths (Walsh, 2000). Data from Spain show that economic expansions are associated with greater rates of occupational injuries, occupational disease, and traffic injuries during work commutes (Boix et al., 1997; Tapia Granados, 1994).

Additional working time reduces sleep, and sleep decreases with increasing wages (Biddle and Hamermesh, 1990). As hours worked are clearly procyclical, sleep is probably countercyclical - more so if we assume that wages and salaries are also procyclical, as seems to be the case (Thomas, 1925; Blanchflower and Oswald, 1994; Abraham and Haltiwanger, 1995). Reduced sleep can increase stress levels, decrease alertness, and raise the risk of injuries in and out of work, and has also recently been associated with metabolic disturbances related to diabetes (Spiegel et al., 1999). Sexual activity, which has been suggested as protective of the risk of death in middle-aged men (Davey Smith et al., 1997), might also be reduced by overwork and lack of sleep.

A major factor linking economic upturns with increasing mortality is deaths due to traffic injuries. Traffic injuries and deaths are strongly correlated with indices of industrial production (Baker et al., 1984). Business expansions increase both commercial and recreational driving, and the larger the volume of traffic, the larger the probability of crash and death. A large 
portion of driving is for recreational motives (NSF, 1991), and this portion is the one most associated with alcohol consumption. The increase in both regular and binge consumption of alcohol when unemployment drops (Ruhm, 1995, 2003; Freeman, 1999) may be an additional reason for the procyclical character of traffic mortality.

Changes in the level of economic activity may affect everyone - employed, unemployed, or not in the labor force - through effects on the social fabric (Figure 1). Social isolation has been shown to be related to adverse health outcomes (Berkman and Syme, 1979; Kasl and Wells, 1985; Cohen and Syme, 1985; Seeman and Berkman, 1988; Falk et al., 1992). It has been suggested that overwork can have detrimental effects on other family members through a reduction of both psychological and material support (e.g., help with housework) in the home (Sparks et al., 1997). It seems very plausible that the general level of social support is reduced during business expansions by overwork and overtime, lack of time for social interaction, and internal migration. In Spain, it is common for married offspring and parents to live in the same town. Moving to another town because of a new job may therefore produce social isolation in the migrant and also in the elderly relatives who stay behind. At the international level, migration has been shown to be procyclical with respect to the receptor country (Thomas, 1925, 1941; Sáez, 1975; Higgs, 1979; Chernomas, 1984) and migration between regions within a country is likely to follow a similar procyclical pattern.

There also appears to be a causal link between stress, decreased immunity, and higher incidence of infections (Kiecolt-Glaser et al., 2002). Previous work has found that infectious disease mortality increases in economic expansions (Thomas, 1925; Eyer, 1977a; Higgs, 1979; Ruhm, 2000). The occurrence of a mild infection can lead to fatal illness in persons with underlying chronic disease - but the death certificate shows only the ultimate cause of death, such as heart disease or cancer.

Pollution from motor vehicles and industrial emissions has been shown to be associated with increases in rates of disease and death (Gardner, 1973; Dockery et al., 1993; HEI, 2001). Given the procyclical character of industrial activity and transport, it is quite plausible that air pollution is also procyclical. Noise may also have detrimental effects on health and behavior, including cardiovascular disease and psychiatric disorders (Monahan and Vaux, 1980; Hunt, 1989; WHO, 1992; Steenland, 1996). Because traffic, transportation, and industrial activity are major sources of noise, noise levels are also likely to be procyclical.

Long-term exposure to unhealthy diets, smoking, or drinking is related to the development of chronic disease, and acute increases in consumption of unhealthy foods, cigarettes, or alcohol may also precipitate death in persons with pre-existing disease. In the United States, saturated fat consumption 
drops and physical activity increases during economic downturns (Ruhm, 2003). Smoking also exhibits a strong procyclical fluctuation (Ruhm, 2000, 2003) that can have a direct impact on mortality due to cardiovascular disease, cancer, and respiratory disease. Alcohol consumption - which is also procyclical - may impact mortality through its effects on the risk of injuries. It is also related to mortality from chronic disease (e.g., liver cirrhosis, heart disease), possibly through its effects on immunity and its toxic effects on liver and heart tissue. Liver cirrhosis mortality has been shown to be procyclical (Eyer, 1977b; Ruhm, 2000).

\section{Unemployment as a Risk Factor for Disease and Death}

The aforementioned factors may increase the risk of death during economic upturns, but wouldn't they be compensated by an increase in the risk of death of those who become unemployed when the economy goes into recession?

A large body of literature shows that mortality in the unemployed is higher than in the employed even after adjustment for age and income. The extent to which this reflects a causal effect of unemployment on health is unclear. Issues discussed in the literature (Stern, 1983; Bartlet, 1996; Mathers and Schofield, 1998) include the potential for bi-directional causation (ill health promoting loss of job and loss of employment inducing disease), mediating factors (unemployment causing reduction of income, and this in turn worsening health), and confounding (marginality or poor social adaptation causing both bad health and job loss). The differential in mortality between employed and unemployed is much weaker during recessions, when unemployment surges (Valkonen and Martikainen, 1995; Martikainen and Valkonen, 1996a, b), suggesting that the mortality differential between unemployed and employed may be driven by selection factors or reverse causation. Alternatively, the health effects of unemployment may be modified by the context in which unemployment occurs. For example, the stressrelated consequences of unemployment may be reduced in a recession context when unemployment is widespread (Blake Turner, 1995). Even assuming an increased risk of mortality in the unemployed, the relationship between unemployment levels and mortality in the population as a whole may be driven by changes in the working and consumption conditions of those employed and their families (as discussed in the prior section), since the employed are a large majority in comparison with the unemployed. Thus, an adverse effect of personal unemployment on individual health is not incompatible with an inverse association between population-level unemployment (as a marker of economic activity) and mortality.

Brenner $(1980,1993,1995)$ argued that peaks in mortality coinciding with upturns in the economy result from the lagged effect of high unemployment in a previous recession. Since business "cycles" are very irregular in duration 
and depth, and the time between a recession trough and an expansion peaks varies widely from one "cycle" to the next (Kacapyr, 1996), a procyclical oscillation of mortality resulting from a lagged effect of recession would have to imply a different relevant lag for each cycle. This makes little sense from the point of view of the pathophysiological pathways purported to link unemployment and health. Moreover, though the development of chronic disease, a major cause of death in modern societies, occurs over periods of years, once chronic disease is present, death may be triggered by economyrelated factors with a lag of months, weeks, or even days. In the United States, heart attacks in working individuals peak on Mondays (Ruhm, 2000), suicides are generally highest on Mondays and on non-holidays (Bollen, 1983), and during the first week of the month there is a significant increase of deaths by external causes, circulatory disorders, cancer, and other causes (Phillips et al., 1999). In Israel, Sunday is the day of the week when there are more deaths among Jews, while among Arabs there is no clear pattern (Anson and Anson, 2000). These time patterns not only prove that death is a social event, but also that its concrete timing is subject to influences that have a very short lag.

\section{Data}

Data on mortality, age-structure, and economic statistics for the fifty Spanish provinces in the years 1980-1997 were obtained from the TEMPUS database of the Spanish National Institute of Statistics (INE). Annual deaths for each province were directly downloaded from the INE website (http:// www.ine.es). The denominators of the mortality rates and the explanatory variables were also taken from TEMPUs, which provides intercensal estimates of population for each province and each year in the past decades (in Spain a national census is taken every 10 years). Unemployment rates (unemployed as a percentage of all persons either employed or looking for a job) and employment ratios (the proportion of persons aged 16 or over who are employed), both at the province and national levels, were used as indicators of economic activity. Annual unemployment was estimated by the mean of four quarterly estimates.

Cause-specific mortality was calculated for the five major causes of death cardiovascular disease, cancer, respiratory disease, traffic injuries and infectious disease; and for two qualitatively important causes - suicide and homicide. These seven causes account for almost $80 \%$ of total mortality.

Province real GDP per capita was included as a covariate in some regressions and can be interpreted as an indicator of the average province income, and as an index of province economic activity. It was computed from the fifty series of province GDP at nominal prices taken from the TEMPUS database. The nominal GDP was deflated with a price deflator obtained by 
connecting two series of price deflators taken from TEMPUS : a consumer price index (CPI) series comprising 1939-1992 (with 1983 as the base year) for the province capitals, and a CPI series comprising 1993-2001 (with 1992 as the base year) for the whole province. The two series were connected by transforming the CPI 1993-2001 to the base of the other series.

Table A1 in Appendix A shows the statistics of the dependent and explanatory variables.

\section{Statistical Considerations and Models}

Many criticisms applicable to early studies of the relationship between mortality and business cycles based on a single series of national mortality can be overcome by using panel data. The analysis of a large number of units allows control for time and geographical effects, making spurious results due to misspecification or omitted variables less likely. Panel models with fixed effects reduce the probability of bias present in cross-sectional or time-series analysis due to the inability to adjust the effect estimates for omitted variables that influence mortality and are correlated with economic conditions across locations (in cross-sectional analysis) or over time (in time-series analysis). The specifications used by Ruhm (2000) with the states of the United States were applied here to the 50 Spanish provinces. They were also expanded in several ways.

The natural $\log$ of the province death rate was the dependent variable regressed on demographic and economic covariates. The logarithmically transformed death rate $(\ln d / p)$ is considered normally distributed with variance $1 / \mathrm{E}(d)$, where $\mathrm{E}(d)$ is the expected number of deaths (Robertson and Ecob, 1999). Since $\mathrm{E}(d)$ is proportional to $p$, the variance of $\ln d / p$ is inversely proportional to $p$, the population size, ranging in the Spanish provinces from 100,000 to 5 million. This implies heteroscedasticity of the dependent variable. To compensate for this, observations were weighted by the square root of the denominator of the death rate (Ruhm, 2000). This is similar to converting ordinary least square (OLS) regression into generalized least squares (GLS), weighting by the inverse of the variance of the residuals (Gujarati, 1995).

The relationship between economic conditions and mortality was analyzed using regressions with contemporaneous variables and regressions with lagged variables.

In the models with contemporaneous variables, the first batch of regressions regress province crude death rates (for all causes and for specific causes, or for both men and women and each sex separately) on vectors of variables for contemporaneous economic and age-structure conditions, and dummy variables to control for time (year) or geographic (province) effects. All specifications include dummies for province effects and two age-structure 
variables (the proportion of population under five and the proportion over 64) to adjust the results for age.

In specification $A$

$$
\ln M_{p t}=\psi_{\mathrm{t}}+\pi_{p}+U_{p t} \cdot \beta_{1}+N_{p t} \cdot \gamma_{1}+V_{p t} \cdot \gamma_{2}+\varepsilon_{p t}
$$

$\psi_{\mathrm{t}}$ represents nationwide time effects (year effects) and $\pi_{p}$ are province-specific time-invariant effects; $U_{p t}$ is province unemployment in province $p$ at year $t$ (the proxy measure of economic conditions); $N_{p t}$ and $V_{p t}$ (for niños and viejos) are the age-structure variables, and $\varepsilon_{p t}$ is the error term.

In specification $\mathrm{B}$, the term $I_{p t} \cdot \beta_{2}$ is added to the right-hand side of equation (1), where $I_{p t}$ is province real GDP per capita, so that the unemployment estimate is adjusted for province GDP. Specification $\mathrm{C}$ is analogous to specification A but with the time-effect dummy suppressed so that results are adjusted for province effects, but not for time effects. Specification $\mathrm{D}$ is analogous to specification $\mathrm{C}$, but includes yearly national unemployment instead of province unemployment in order to investigate the effects of the national economy. Finally, specification $\mathrm{E}$ adds province unemployment to specification $\mathrm{D}$, so that national and province unemployment are investigated together.

In a second batch of regressions, the five aforementioned specifications were expanded by adding to the right-hand side of (1) the term $\tau_{p} \cdot t$, in which $\tau_{p}$ is the slope of a province-specific time trend. This amounts to an adjustment for potential province-specific time trends.

Specifications A to E were repeated for cause-specific mortality and then for sex-specific mortality regressed on sex-specific unemployment rates. Models were also run using employment ratios instead of the unemployment rate. Selected specifications were also run including lagged covariates. Finally, models with mortality and explanatory variables expressed in yearto-year change (rather than in levels) were also explored.

\section{Results}

\subsection{RESULTS OF MODELS WITH CONTEMPORANEOUS VARIABLES}

Using the whole sample $(N=900)$, estimates of the province unemployment effect on total death rates were negative and statistically significant for all the specifications (Table 1).

Estimates of the effect of province unemployment ranged from -0.0011 when province-specific time trends are included to -0.0035 when they are not. The examination of the residuals reveals indeed some linear patterns in the specifications without trend controls; therefore, it seems safer to choose -0.0011 as the size of the effect. This implies a drop in mortality of around 
RECESSIONS AND MORTALITY IN SPAIN

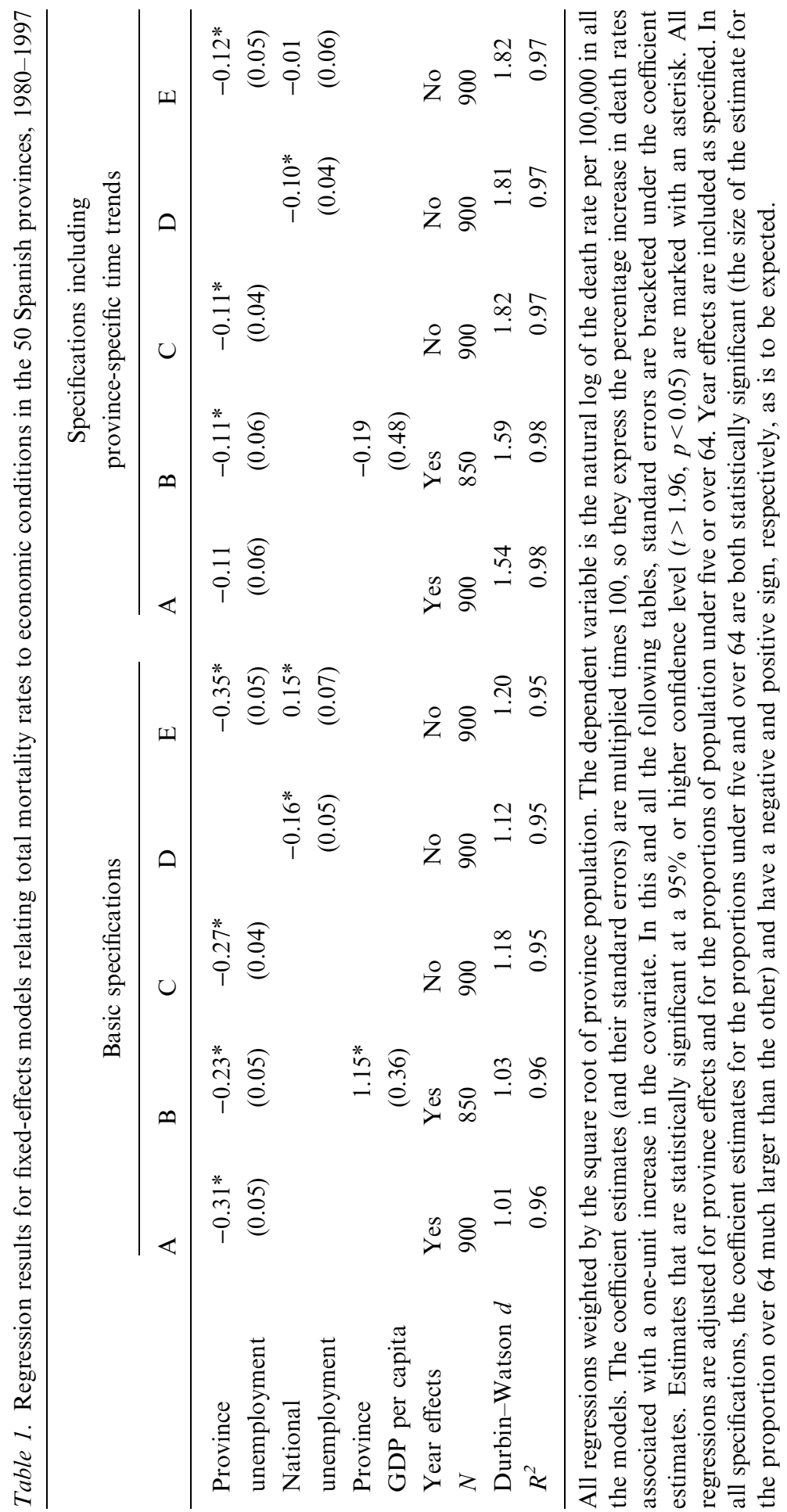


$0.11 \%$ per percentage point of increase in province unemployment. At the average values of province mortality and unemployment in the period considered, the relative change in mortality with respect to the relative change in unemployment, i.e., the unemployment elasticity of mortality, is $-0.021=-2.1 \%$ (because $0.0011 /[1 / 19.3]=0.0212$ ). In gross terms, an increase of 5 percentage points in the unemployment rate (quite moderate by Spanish standards), for instance from $10 \%$ to $15 \%$, will be associated with a reduction of about $0.55 \%$ in mortality. Since the Spanish population is 40 million, an increase in unemployment of 5 percentage points would "save" some 1800 lives $\left(5 \cdot 0.0011 \cdot\left[827 / 10^{5}\right] \cdot 40 \cdot 10^{6}=1819\right)$.

The results were relatively robust with respect to changes in specification. Estimates for selected sets of provinces suggest a stronger effect in the provinces with population over one million and in the provinces with the largest GDP in 1990. Checking to see if the inclusion in the regressions of the proportions of province populations under five and over 64 was an insufficient adjustment for the age-structure of the population, regressions were also run with additional terms for the proportions of population over 74 and over 84 . These regressions rendered results almost identical to those reported. Also, since the Durbin-Watson $d$ in some of the OLS regressions reported (Table 1) indicated positive autocorrelation of the residuals (mainly in some of the specifications without province-specific time trends), regression estimates were also computed with adjustment for autocorrelation. The estimates were almost identical to those reported.

When sex-specific death rates are the dependent variable (Table 2), the estimates for the effect of province unemployment are quite similar to those obtained with total (male and female) mortality as the dependent variable (Table 1), but the unemployment effect appears slightly stronger for male deaths.

In the analyzed sample the mean employment ratio is $56.2 \%$ for men and only $23.7 \%$ for women, but Spain is not an exception to the general rule that men have a stronger involvement in monetary-economy activities compared with women. Thus, it is to be expected that in an economic-demographic model, economic indicators will predict mortality in males better than in females. Indeed, the absolute values of coefficient estimates for unemployment are larger for male than for female mortality. Comparing the sexspecific coefficient estimates (Clogg et al., 1995), the differences are not statistically significant in some models (for instance, specification A without time trends, $-0.0031 \pm 0.0005$ vs. $-0.0030 \pm 0.0005$ ) but they are marginally significant in others (specification A with time trends, $-0.0016 \pm 0.005$ vs. $-0.0006 \pm 0.0006, p=0.08)$. 
RECESSIONS AND MORTALITY IN SPAIN

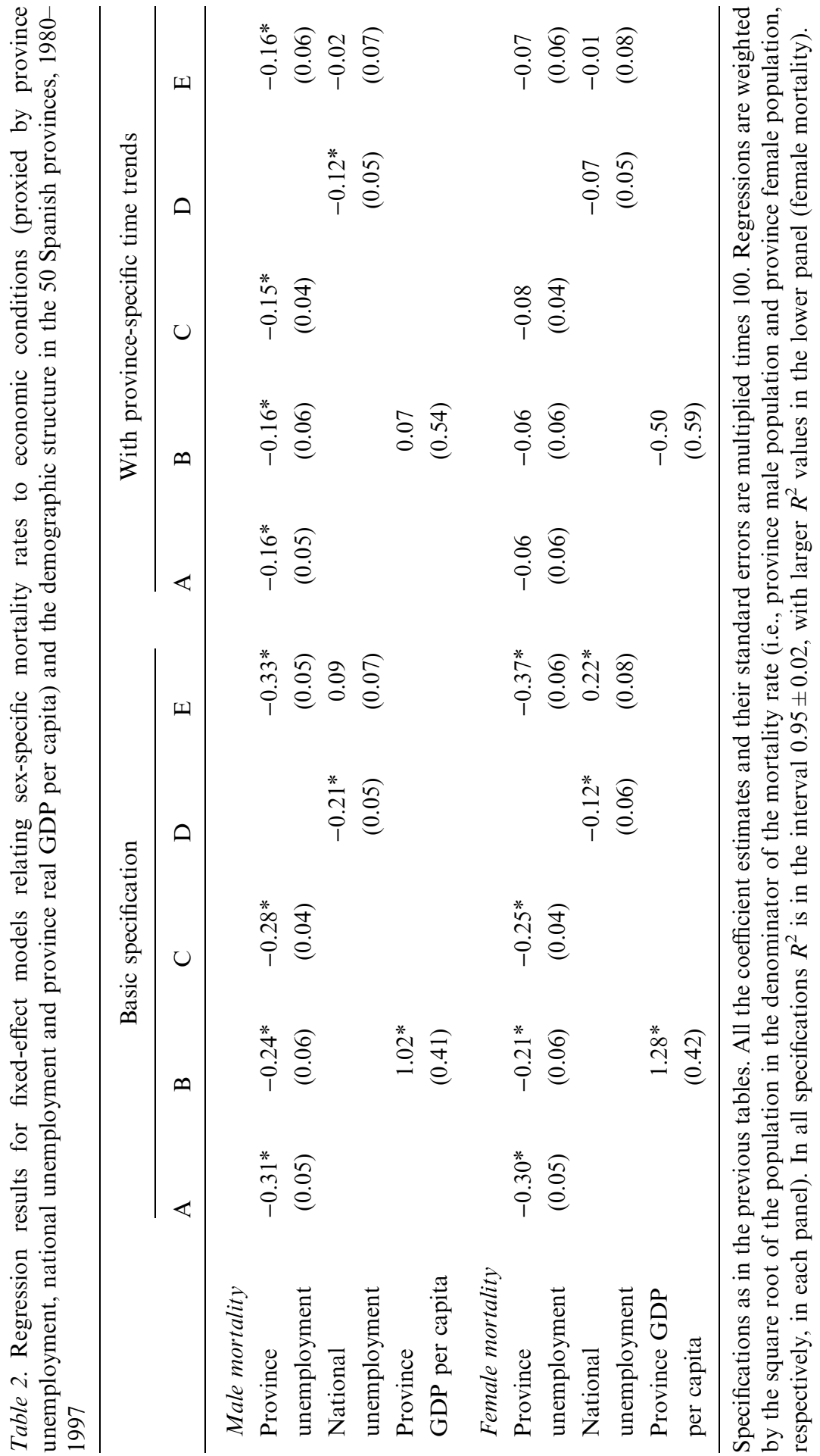


The regressions for sex- and cause-specific death rates modeled as a function of general unemployment yield results similar to those for total (male and female) cause-specific mortality (results not shown).

In specifications in which the two sex-specific unemployment rates were used as covariates simultaneously, the effect of the province male unemployment rate on total death rate (men and women) is consistently negative and statistically significant most of the time, while the estimates of the province female unemployment effect are much smaller, generally not statistically different from zero (results not shown). It can be hypothesized that this is a result of the changes in female unemployment being a weaker indicator of the status of the economy than the changes in male unemployment.

Since the unemployment rate does not take into account persons who are retired, exclusively involved in housework, or simply discouraged from finding a job, the employment ratio is a better indicator of the extent of involvement of the general population in the market economy. If sex-specific unemployment rates have a statistically and demographically significant negative effect on mortality because they serve as proxies for the general level of economic activity, one might expect effect estimates with the opposite sign and with similar statistical significance when the employment ratio is used as an alternate indicator of economic activity. This is precisely the case. When sex-specific employment ratios were used as covariates instead of sex-specific unemployment rates, the effect of the province male employment ratio is strongly positive, for general mortality as well as for both male and female sex-specific mortality (results not shown).

Death rates also appeared to be procyclical in differenced models in which annual changes in mortality were regressed on annual changes in explanatory variables (see Appendix B).

In summary, models with contemporaneous variables show a consistent effect of province unemployment rates (negative effect) or employment ratios (positive effect) on mortality. In general, there is no evidence of an effect of national unemployment on total mortality when province unemployment is included in the model, although national unemployment seems to have a specific impact on some specific causes of death, as will be discussed in more detail below.

\subsection{RESULTS FROM MODELS WITH LAGGED EFFECTS}

In models including terms both for contemporaneous and lagged (up to 4 years) unemployment (results not shown), most specifications without province-specific time trends show a weakening toward zero of the effect of province unemployment on mortality as the time lag increases. In specification A, the estimates for lagged unemployment are, respectively, -0.0019 , 
$-0.0011,-0.0009,-0.0001$, and -0.0002 for the lags $0-4$ (only the zero-lag coefficient is significant at the 0.05 significance level). The sum of the coefficient estimates for province unemployment from lag 0 to lag 4 is, respectively, $-0.0042,-0.0038$, and -0.0036 for specifications $\mathrm{A}, \mathrm{B}$, and $\mathrm{C}$. In specification $\mathrm{D}$, the sum of coefficient estimates for national unemployment is -0.74 , but some of the coefficients are positive and significant. The coefficient estimates for lagged national unemployment in specifications with or without province-specific time trends, and the coefficient estimates for province unemployment in the specifications with province-specific time trends reveal an alternating pattern, with statistically significant positive and negative estimates for unemployment at consecutive lags. The absolute value of these estimates is larger for larger lags. This pattern, common in time series regressions when lagged variables are introduced (Palloni and Hill, 1997), seems to reflect only statistical instability of the coefficients due to collinearity, rather than real effects with switching signs. The high first-order autocorrelation between unemployment rates ( 0.95 in this sample) is very likely the source of these results.

\subsection{THE EFFECT OF PROVINCE REAL GDP PER CAPITA ON MORTALITY}

The estimate of the effect of province GDP on general mortality or sexspecific mortality (Tables 1 and 3 ) is positive and statistically significant in all specifications without province-specific time trends. The effect disappears when province-specific time trends are included. In regressions with causespecific mortality as the dependent variable and no province-specific time trends, province GDP had statistically significant effects on most causes of death (though with different signs), but when province-specific time trends are included (results not shown) almost all effects of GDP are no longer significant. This pattern might be interpreted as if GDP were simply capturing an omitted linear trend in models without province-specific time trends. However, graphs of province GDP per capita over time reveal substantial oscillations throughout the 18-year period, and no clear evidence of a linear trend. The population-weighted correlation of province unemployment and province GDP per capita is -0.24 for the whole sample $(N=850)$ and is positive for 44 provinces. Therefore, collinearity between GDP and unemployment does not seem to be a complete explanation for these effects. While the effect of province unemployment on mortality is robust, not revealing sensitivity to specification, the effect of province GDP per capita on mortality is strongly dependent on specifications. These inconsistent effects require further investigation. 


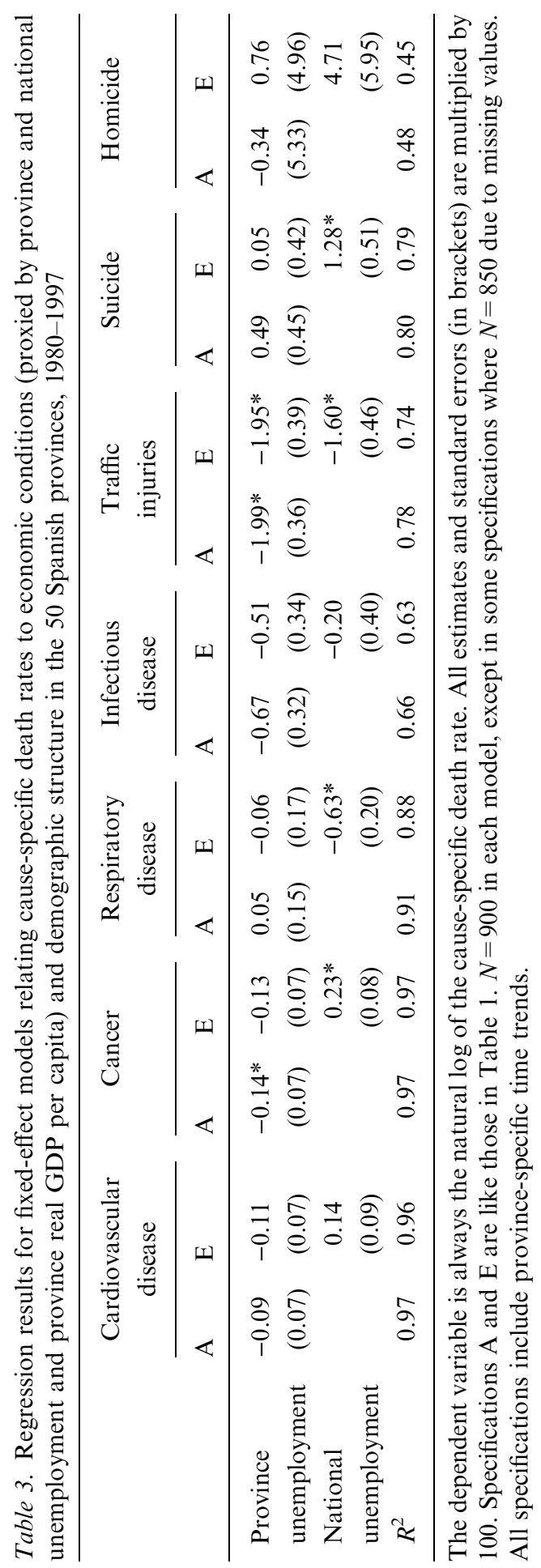




\subsection{THE EFFECTS ON MORTALITY DUE TO SPECIFIC CAUSES OF DEATH}

When cause-specific death rates are the dependent variable (Table 3), the results are quite consistent with those for general mortality. Except for some specific causes of death which will be discussed below, estimates of the effect of province unemployment are negative, though they are not always statistically significant.

The estimates of the effect of province unemployment on cardiovascular mortality suggest that cardiovascular deaths are very weakly procyclical in this sample. The unemployment estimates for cardiovascular mortality in the total population and in men are negative and significant only in some specifications without province-specific time trends (not shown). Female cardiovascular mortality does not seem to be related to unemployment.

Cancer mortality appears procyclical with respect to local unemployment rates or employment ratios. The estimates of the effect of unemployment are statistically significant in almost all specifications without province-specific time trends (not shown), but they are only marginally significant when province-specific time trends are added. However, cancer mortality seems to be procyclical with respect to local conditions and countercyclical with respect to national conditions.

Mortality due to respiratory disease appears to be procyclical for males with respect to local unemployment in specifications without province-specific time trends (not shown). In specifications with province-specific time trends, mortality due to respiratory disease is not related to local unemployment, but is intensely procyclical with respect to national unemployment.

Mortality due to infectious disease (Table 3 ) decreased about $0.6 \%$ for each percentage point increase in province unemployment. The elasticity of mortality due to infectious disease is 0.12 with respect to province unemployment, which is about six times larger than the elasticity of general mortality. The estimate is statistically significant in most specifications without province-specific time trends and marginally significant in the others.

Mortality due to traffic injuries is very strongly procyclical with respect to both local and national conditions. While the unemployment elasticity of general mortality is -0.021 , that of traffic mortality is -0.37 , i.e., almost 18 times higher.

Suicide is the only cause of death in which results across specifications show a pattern of intense effect of national conditions and no effect of local conditions (Table 3). On the other hand, total suicides and male suicides increase significantly when national unemployment rises (the effect of the economy on female suicides, if any, is unclear). Therefore, suicide is the only cause-specific mortality that oscillates countercyclically in this sample.

Homicides for both total population (Table 3) and for males seem to be unrelated to both local and national economic conditions in this sample. 
However, estimates of the effect of unemployment (or employment) on female homicide are negative (positive), marginally significant in some specifications and significant in others (results not shown). This and the large number of zeros in the data does not allow us to affirm without doubt that female homicides are procyclical in this sample.

\section{Discussion}

The results of this study reflect a population-level relationship: mortality is higher when more people are employed and lower when unemployment rises. The analysis does not investigate the effect of unemployment per se on health (i.e., the individual level effect of being unemployed). Rather, national and province unemployment rates are proxies for the state of the national and the local economy, respectively. The persistent negative signs of the estimate for the effect of unemployment (or positive signs for the effect of employment) across a wide array of specifications and specific causes of death provide substantial evidence of an increase in mortality associated with the expansions of the economy. Using unemployment as indicator of the business cycle, mortality is procyclical, and the relationship is robust with respect to different specifications. The population-level relationship between unemployment rates and mortality is of special interest because it reveals an effect in a direction opposite to the expected individual-level effect.

If a panel regression with fixed effects for subunits (provinces) of a large unit (the nation) is to provide better estimates of an effect than those derived from the time series analysis of the large unit data, the fluctuations of the covariates corresponding to the subunits must be to some extent independent across these subunits. In this sample, the 1225 correlations between province unemployment rates are in the range -0.41 to 0.99 , with a median of 0.72 (mean $\pm \mathrm{SD}=0.66 \pm 0.24$ ). The correlations of the fifty province unemployment rates with the national unemployment rate range from 0.30 to 0.96 , with a median of 0.85 (mean $\pm \mathrm{SD}=0.81 \pm 0.13$ ). This indicates that unemployment oscillations across provinces are obviously correlated, though they also have a degree of independence. The correlations between province and national unemployment are for some provinces high enough to generate an important degree of collinearity in specification $\mathrm{D}$, in which both province and national unemployment are included. This is probably the reason for national and province unemployment estimates with opposite signs in specification $\mathrm{D}$ in a number of models.

The province-invariant fixed-effect dummies for time (year) adjust estimates of the impact of the economy on mortality for nationwide time effects. Estimates derived from specifications with a year dummy variable are therefore free of biases due to the presence of linear or non-linear trends that affect the mortality data in the same way across provinces. The specifications 
in which province-specific time trends are included go a step further toward eliminating spurious effects due to time trends, in this case linear trends with different slopes for each province. The persistence of the negative association of unemployment with mortality after adjusting for these time trends highlights the robustness of the effect.

The size of the effect, a reduction of mortality of about $0.11 \%$ per percentage point of increase in province unemployment, is less than a fourth of that found by Ruhm (2000), whose estimates from a similar analysis of the states of the United States ranged around $0.5 \%$. Ruhm's estimates are more similar in size to estimates for the Spanish provinces with larger populations or higher GDP per capita. The unemployment elasticity of mortality found by Ruhm in the states of the United States is -0.04 , that is, about twice the unemployment elasticity found in this study $(-0.021)$ for the mortality of the Spanish provinces.

The procyclical oscillation of mortality for general mortality and for the seven causes of death investigated except suicide, which oscillates countercyclically, is largely consistent with the results of Ruhm (2000) and Neumayer (2004a, 2004b). Although Neumayer found suicide moving procyclically in Germany (the reunification may be a factor there), the countercyclical oscillation of suicide found in the Spanish provinces is consistent with Ruhm's results for the United States (Ruhm, 2000), as well as with previous studies showing that suicide rates increase during recessions (Dooley et al., 1996), and that suicide rates and unemployment levels are positively associated across countries (Boor, 1980; Bollen, 1983).

During the years included in the study, age-adjusted mortality was generally falling and unemployment was generally rising. It could therefore be argued that linear regression will show an average "negative" spurious relationship resulting from secular trends in both variables. However, the negative effect estimates for unemployment appear in all types of specifications, even in those with year dummies or with both year dummies and province-specific time trends. If the negative relationship between unemployment and mortality were entirely dependent on secular trends, it should be eliminated by these statistical procedures. Moreover, the negative relationship is also present when first differences (or rate of change) in mortality are regressed on first differences (or rate of change) in the regressors.

Though the estimates for the effect of national unemployment are negative and significant in the specifications where province unemployment is not included (specification C, Tables 1 and 3), province unemployment is generally a better predictor for general or specific mortality rates than national unemployment when both are included in regressions (specification $\mathrm{D}$, Tables 1-3). This is consistent with the notion that there should be a greater impact on population health from local economic conditions than from national economic conditions. In addition, in the various models for general 
mortality (Table 2) or cause-specific mortality for males and females (results not shown), the $R^{2}$ for male mortality regressions is larger than that for female mortality ones, suggesting that the level of unemployment or employment predicts male mortality better than female mortality. Female death rates seem to be less dependent on the fluctuations of the economy than are male death rates. As previously stated, it is to be expected that a model with economic and demographic covariates will predict death rates in males better than in females.

In regressions for cause-specific death rates (Table 3), there are large differences in $R^{2}$ values. Since the population proportions under five and over 64 are included in all models, $R^{2}$ values are high (over 0.9) when advanced age is a strong predictor of death (as in mortality due to cardiovascular disease, cancer and respiratory disease), and lower in the other causes of death (only 0.46 for homicide). This provides some evidence of biological plausibility of the models.

A factor that has an effect on short-term mortality but has not been included in the present study is extreme weather, which is consistently related to increased mortality, mostly of elderly people (Gardner, 1973; HEI, 2001). Meteorological data are not included in the models in the present study because of the difficulty of choosing a good synthetic indicator of annual weather and also because today, business-cycle models à la Jevons, based on weather, lack credibility among social scientists of all creeds. If weather influences mortality but does not correlate with economic fluctuations, its exclusion from the models will not result in omitted variable bias.

The study does not include covariates that are consumption-related (e.g. smoking, caloric intake, intake of fruits and vegetables, medical care, exercising), or production-related (e.g. overwork, overtime, exposure to industrial pollutants, etc.) that very likely fluctuate with the level of economic activity. However, if changes in the status of the economy are associated with changes in behaviors or exposures, these factors may be best thought of as mediating mechanisms rather than confounders of the business cycle-mortality relationship. Additional work is needed to investigate the specific mediators of the effects reported here.

\section{Final Remarks}

According to Mason (1997: 28), recent studies in Third World countries agree that "economic crises and structural adjustment typically have not led to an increase in mortality," though several studies provide support for the view that mortality decline slowed in these countries during the 1980s. Indeed, authors looking in recent years for health impacts of economic slumps, for instance, in Latin American countries, have often found unexpected results (Tapinos et al., 1997). Palloni and Hill (1997) studied the short-term mortality responses to recessions in the second half of the $20^{\text {th }}$ century in nine Latin American 
countries, and found them erratic, contrary to expectations, and not statistically significant. Ortega-Osona and Reher (1997), Abdala et al. (2000) and Rios-Neto and Carvalho (1997) have reported results revealing positive and statistically significant associations between GDP growth and crude, infant, or adult mortality in $20^{\text {th }}$ century data from Argentina, Chile, and Brazil. All these authors commented on the unexpected and surprising character of these findings.

If recent Latin American studies provide a unforeseen view of the shortterm effects of recessions on mortality rates in low-income countries, the historically unprecedented and outsized rises in mortality during the transition and crisis period of the early-mid 1990s in the countries of Eastern Europe and the former USSR (Cornia and Paniccià, 2000) might be considered as supporting the case for a countercyclical link between mortality upswings and recessions. However, it is difficult to view the sudden and abrupt breakdown of the political, social, and economic institutions of the Soviet block countries as analogous to the recessions or economic downturns that periodically recur in consolidated market economies. Moreover, the striking increases in death rates that took place in Eastern Europe during the 1990s were basically due to cardiovascular deaths, homicides, suicides, and other non-infectious causes of adult mortality (McKee, 2001) that do not fit well in the Malthusian framework. According to Gavrilova et al. (2003), life expectancy has continued declining in Russia after 1998.

Results of empirical studies are still conflicting and there is still much to be clarified regarding the relationship between economic fluctuations and health. In industrial advanced economies the procyclical oscillation of mortality has not been replicated in all samples (Gerdtham and Johannesson, 2005), but in modern studies mortality has been found procyclical almost without exception (Ruhm, 2000; Gerdtham and Ruhm; 2002; Neumayer, 2004a, b, Ruhm, 2004; Laporte, 2004, Tapia Granados, 2004, 2005). Ruhm (2003) has also shown, using a large dataset of individual data, that morbidity and behaviors that are harmful for health increase during expansions of the economy.

The present investigation adds Spain to the list of empirical results confirming the observations of demographers, epidemiologists, and economic historians who again and again noticed with surprise that over declining secular trends, in the short-term mortality oscillated "in the wrong way," rising during "good times" and falling during recessions. A convergence of empirical results seems to be arising indicating that in industrialized economies death rates oscillate in a procyclical way. From this it would be non-sensical to deduce as policy implication the endorsement of economic policies promoting economic recessions to reduce mortality. However, these results must moderate the enthusiasm about the all-encompassing virtues of economic growth and emphasize the need to investigate the factors influencing the long-term decline in mortality. 
To argue in favor of expansionary economic policies because of the assumed short-term harmful health effects of recessions - as was often done in the past - seems to run counter to empirical evidence. In contrast, the procyclical character of mortality fluctuations, now well established in quite different industrial economies, seems to argue in favor of public health policies to offset the harmful effects of economic expansions on health. As the present results from Spain show, the case is especially evident for deaths due to traffic. Traffic-related injuries are strongly influenced by business upturns and kill or disable people at all ages, including a large proportion of adolescents and young adults, therefore generating a heavy loss of potential years of healthy life.

\section{Acknowledgements}

I wish to thank Guido de Marco and Friedrich Huebler for their invaluable help in downloading and processing the data, and Eugene Canjels and Christopher Ruhm for their useful comments. Duncan Foley made many suggestions and thoughtful criticism, and Ana Diez Roux provided valuable support in a variety of ways. The paper has also benefited greatly from the comments of anonymous reviewers.

\section{Appendix A}

Table A1. Weighted mean and standard deviation of the outcome variables and covariates

\begin{tabular}{lcr}
\hline Variable & Weighted mean & SD \\
\hline Death rate per 100,000 & & \\
All causes & 827.0 & 141.4 \\
Men & 891.6 & 147.7 \\
Women & 765.0 & 139.4 \\
Cardiovascular disease (390-459) & 345.6 & 73.9 \\
Men & 322.2 & 70.7 \\
Women & 368.0 & 81.1 \\
Cancer (140-239) & 196.0 & 39.9 \\
Men & 243.5 & 53.3 \\
Women & 150.3 & 29.4 \\
Respiratory disease (460-519) & 76.5 & 19.9 \\
Men & 94.3 & 25.6 \\
Women & 59.5 & 16.9 \\
Infectious disease (001-139) & 9.7 & 3.1 \\
Men & 11.3 & 3.8 \\
Women & 8.3 & 3.2 \\
\hline
\end{tabular}


Table A1. (Continued)

\begin{tabular}{lcc}
\hline Variable & Weighted mean & SD \\
\hline Traffic injuries & 15.7 & 5.7 \\
$\quad$ Men & 24.4 & 8.9 \\
$\quad$ Women & 7.3 & 3.4 \\
Suicide & 6.9 & 3.0 \\
$\quad$ Men & 10.5 & 4.6 \\
Women & 3.6 & 2.0 \\
Homicide & 0.9 & 0.7 \\
$\quad$ Men & 1.4 & 1.1 \\
$\quad$ Women & 0.5 & 0.5 \\
Annual average rates of unemployment or employment (\%) & & \\
Unemployed among all active men and women & 19.3 & 7.2 \\
Unemployed among active men & 16.1 & 6.7 \\
Unemployed among active women & 25.3 & 9.5 \\
Province GDP per capita, in hundreds of thousands of 1983 pesetas & 7.1 & 1.8 \\
Population aged 0-4 years (\%) & 6.0 & 1.4 \\
Population aged $>64$ (\%) & 13.3 & 3.8 \\
\hline
\end{tabular}

Means weighted by province population. Quarterly unemployment taken directly from TEMPUS. Employment ratios computed from unemployment and rates of activity among persons older than 16. Province real GDP per capita computed from province nominal GDP, from TEMPUS (data for 1994-1996 are provisional), and two series of consumer price index from TEMPUs. There are 900 observations (one for each year of the 18-year-period, 1980-1997, for each of the 50 provinces) for all variables except province GDP per capita, where $N=850$ (the province GDP series reach only 1996). Bracketed codes refer to the $9^{\text {th }}$ Revision of the International Classification of Disease (ICD9). The "cancer" category in this table corresponds in the TEMPUS database to deaths classified as caused by tumores (tumors), with ICD-9 codes 140-239, including the solid malignant neoplasms (ICD-9 codes 140-199), leukemia, lymphomas, Hodgkin's disease and other malignant neoplasm (codes 200-208, 230-234, 235-238, 239), and benign neoplasms (210-229). The group includes a very small group of deaths caused by tumors that are not malignancies (cancer) in the strict sense. Mortality due to respiratory diseases (460-519) includes deaths allocated to a large miscellaneous group of chest disorders, including infectious and non-infectious diseases. According to TEMPUS data, in Barcelona, in 1990, 3\% of this group of respiratory disease deaths were due to influenza, $19 \%$ to pneumonia, $18 \%$ to chronic bronchitis, emphysema or asthma, and $60 \%$ to miscellaneous chest disorders - pneumoconiosis, lung abscess, pleurisy, atelectasis, respiratory failure, etc. Therefore, about $20 \%$ of this group of respiratory disease deaths were directly caused by acute infection and $80 \%$ were fatalities in patients with a background of chronic lung disease. Mortality by infectious disease corresponds to "infectious and parasitic diseases" (ICD-9 codes 001-139) in TEMPUS. It includes cholera and other bowel infectious diseases, tuberculosis, meningococcal infections, viral encephalitis, viral hepatitis, syphilis and other venereal diseases, and other infectious and parasitic diseases, excluding acute respiratory infections (460-466), pneumonia and influenza (480-487) and AIDS (279.5). Total suicide and male suicide rates were zero in 200 out of the 900 observations. Female suicides were zero in 218 observations. The homicide rate was zero for all homicides in 257 observations, for male homicide in 293 observations, and for female homicide in 519 . These zero rates were corrected to $10^{-11}$ to avoid computational errors when logtransforming the data. 


\section{Appendix B}

\section{REGRESSIONS WITH VARIABLES IN DIFFERENCES}

Autocorrelation in death rates (0.947 in this sample) can generate autocorrelation in the residuals. This does not bias the results, but shrinks the standard error of the estimates producing spurious statistical significance (Gujarati 1995). The fixed effects for province and year, and the provincespecific trends in the panel data analysis, attempt to solve this problem and apparently solve it to a large extent, as judged by the values of the DurbinWatson $d$ close to 2.0 showing very low autocorrelation of the residuals in most specifications with province-specific trends (Table 1).

A way to deal with autocorrelation is to fit models in which difference in mortality is modeled as a function of differences in the explanatory variables. The logarithmic difference of the death rate $\left(\ln M_{p t}-\ln M_{p t-1}\right)$ and first difference of death rates $\left(M_{p t}-M_{p t-1}\right)$ were regressed on first differences of the explanatory variables. Also, rate of change in mortality $\left(\left[M_{p t}-M_{p t-1}\right] /\right.$ $M_{p t-1}$ ) was regressed against the rates of change of the explanatory variables. The time fixed effect of the differentiated equation (1) will be $\psi_{t}-\psi_{t-1}$; therefore, the regressions were run with dummies for year in the specifications A and B and without year dummies for all the other specifications. No province dummies were used for these specifications as the differencing makes the term $\pi_{p}$ (the province fixed effect) redundant. However, the result of differencing the specifications including province-specific time trends implies a province dummy, since $\tau_{p} \cdot t-\tau_{p} \cdot(t-1)=\tau_{p}$. Therefore, specifications with province dummies $\tau_{p}$ and with or without year dummies were computed as differenced versions of the specifications with province-specific time trends. The five basic specifications and five specifications with province-specific trends (Table 1) rendered thirty specifications with mortality in logarithmic, absolute or relative difference.

In unweighted regressions with mortality in first differences (logarithmically transformed in ten regressions, in levels in the other ten regressions), or in relative change (another ten regressions), $R^{2}$ values drop considerably compared to non-differenced equations. In most of these specifications the demographic variables have the expected sign (negative for the proportion under five and positive for the proportion over 64). The coefficient for province unemployment is negative in 20 of the 24 specifications in which it is included. Neither the two demographic variables nor unemployment have significant effects, probably due to both negative autocorrelation and heteroskedasticity. Year-to-year changes in mortality have a strong negative autocorrelation $(-0.201$ in this sample), probably caused by what has been referred to as the "harvesting effect" (Zeger et al., 1999), i.e., years when many high-risk people die are followed by years with fewer deaths. Negative 
autocorrelation of the dependent variable generates negative autocorrelation of the residuals and enlarges standard errors (Søgaard, 1992), making the estimates spuriously non-significant.

The Glejser test (Koutsoyiannis, 1977: 186-189) applied to these regressions indicated the presence of heteroskedasticity, with the residuals being correlated with $\left[V_{p t}-V_{p(t-1)}\right]^{2}$, i.e., the square of the differenced proportion of population over 64. To compensate heteroskedasticity, the 30 aforementioned specifications were run as weighted OLS regressions, weighting by the inverse of the variance of the residuals, which amounts to using GLS (Gujarati, 1995: 362-365). The weights were $1 /\left[V_{p t}-V_{p(t-1)}\right]^{2}$ for the 20 regressions in which $\ln M_{p t}-\ln M_{p t-1}$ or $M_{p t}-M_{p t-1}$ were regressed on first differences of the explanatory variables, and $1 /\left[\left(V_{p t}-V_{p(t-1)}\right) / V_{p(t-1)}\right]^{2}$ in the specifications with $\left[M_{p t}-M_{p t-1}\right] / M_{p t-1}$ as dependent variable. The weighted regressions show a much better fit than the unweighted ones in terms of $R^{2}$. Among these thirty regressions, 24 include an estimate for province unemployment, which is negative in 20 specifications and statistically significant in 18 of them. These results seem to confirm that the effect of the change in province unemployment on mortality change is negative, so that an increase in province unemployment is associated with a drop in mortality.

More details about these and other models not fully presented in this paper can be found in the second chapter of the author's dissertation (Tapia Granados, 2002).

\section{References}

Abdala, F., Geldstein, R. N. and Mychaszula, S. M., 2000. 'Economic restructuring and mortality changes in Argentina - Is there any connection?' in G. A. Cornia and R. Paniccià (eds), The Mortality Crisis in Transitional Economies. Oxford: Oxford University Press, 328-350.

Abraham, K. G. and Haltiwanger, J. C., 1995. 'Real wages and the business cycle', Journal of Economic Literature 33, 1215-1264.

Adams, O. B., 1981. Health and Economic Activity: A Time-series Analysis of Canadian Mortality and Unemployment Rates. Health Division Statistics Canada, Ottawa.

Anson, J. and Anson, O., 2000. 'Thank God it's Friday: the weekly cycle of mortality in Israel', Population Research and Policy Review 19, 143-154.

Arno, P. S., 1984. The Political Economy of Industrial Injuries. PhD Dissertation, New School for Social Research, New York.

Baker, S., O’Neill, B. and Karpf, R., 1984. The Injury Fact Book. Lexington Books, Lexington, MA.

Bartlet, M., 1996. 'Unemployment and health selection', Lancet 348(9032), 904-905.

Berkman, L. F. and Syme, S. L., 1979. 'Social networks, host resistance, and mortality: a nine-year followup study of Alameda County residents', American Journal of Epidemiology 109, 187-197.

Biddle, J. E. and Hamermesh, D. S., 1990. 'Sleep and the allocation of time', Journal of Political Economy 98, 922-943.

Blake Turner, J., 1995. 'Economic context and the health effects of unemployment', Journal of Health \& Social Behaviour 36, 213-229.

Blanchflower, D. G. and Oswald, A. J., 1994. The Wage Curve. MIT Press, Cambridge, MA. 
Bloomberg, L., Meyers, J. and Braverman, M. T., 1994. 'The importance of social interaction: a new perspective on social epidemiology, social risk factors, and health', Health Education Quarterly 21(4), 447-463.

Boix, P., Ors, E., López, M. J. and Rodrigo, F., 1977. 'Trabajo temporal y siniestralidad laboral en España en el período 1988-1995', Cuadernos de Relaciones Laborales (Madrid) 11, 275-320.

Bollen, K. A., 1983. 'Temporal variation in mortality: a comparison of US suicides and motor vehicle fatalities 1972-1976', Demography 20, 45-59.

Boor, M., 1980. 'Relationship between unemployment rates and suicide rates in eight countries, 19621976', Psychological Reports 47, 1089-1101.

Brenner, M. H., 1971. 'Economic changes and heart disease mortality', American Journal of Public Health 61(3), 606-611.

Brenner, M. H., 1976. 'Estimating the social costs of national economic policy: implications for mental and physical health, and criminal aggression', Joint Economic Committee of Congress Paper No. 5. Washington, DC: US Government Printing Office.

Brenner, M. H., 1980. 'Industrialization and economic growth: estimates of their effects on the health of populations', in M. H. Brenner, A. Mooney and T. J. Nagy (eds), Assessing the Contributions of the Social Sciences to Health. Boulder, CO: Westview Press/AAAS, 65-115.

Brenner, M. H., 1993. 'Health and the national economy', Research in Human Capital and Development 7 , 369-391.

Brenner, M. H., 1995. 'Political economy and health', in B. C. Amick, S. Levine, A. R. Tarlov and D. C. Walsh (eds), Society and Health. New York: Oxford University Press, 211-246.

Bunn, A. R., 1979. 'Ischaemic heart disease mortality and the business cycle in Australia', American Journal of Public Health 69, 772-781.

Bunn, A. R., 1980. 'I[schemic]H[eart]D[isease] mortality and the business cycle in Australia [letter]', American Journal of Public Health 70(4), 410-414.

Catalano, R., 1997. 'The effect of deviations from trends in national income on mortality: the Danish and USA data revisited', European Journal of Epidemiology 13, 737-743.

Chernomas, R., 1984. 'A comparative view of the relationship between the business cycle and mortality, 1871-1900', International Journal of Health Services 14, 127-133.

Clogg, C. C., Pretkova, E. and Haritou, A., 1995. 'Statistical methods for comparing regression coefficients between models', American Journal of Sociology 100(5), 1261-1293.

Cohen, S. and Syme, S. L. (eds), 1985. Social Support and Health. Orlando, FL: Academic Press.

Cook, D. G., 1986. 'Can we detect an effect of unemployment on cardiovascular morbidity or mortality?' Postgraduate Medical Journal 62, 801-804.

Cornia, G. A. and Paniccià, R. (eds), 2000. The Mortality Crisis in Transitional Economies. Oxford: Oxford University Press.

Davey Smith, G., Frankel, S. and Yarnell, J., 1997. 'Sex and death: are they related? Findings from the Caerphilly cohort study', British Medical Journal 315, 1641-1644.

Dockery, D. W., Pope, C. A. III, Xu, X., Spengler, J. D., Ware, J. H., Fay, M. E., Ferris, B. J., Jr, Speizer, F. E., 1993. 'An association between air pollution and mortality in six US cities', New England Journal of Medicine 329, 1753-1759.

Dooley, D., Fielding, J. and Levi, L., 1996. 'Health and unemployment', Annual Review of Public Health $17,449-465$.

Eyer, J., 1976a. 'Review of Mental Illness and the Econom', International Journal of Health Services 6, $139-147$.

Eyer, J., 1976b. 'Rejoinder to Dr. Brenner', International Journal of Health Services 6, 157-168.

Eyer, J., 1977a. 'Prosperity as a cause of death', International Journal of Health Services 7, 125-150.

Eyer, J., 1977b. 'Does unemployment cause the death rate peak in each business cycle?' International Journal of Health Services 7, 625-662.

Eyer, J., 1984. 'Capitalism, health, and illness', in J. B. McKinlay (ed), Issues in the Political Economy of Health Care. New York: Tavistock, 23-59.

Eyer, J. and Sterling, P., 1977. 'Stress-related mortality and social organization', Review of Radical Political Economics 9(1), 1-44. 
Falk, A., Hanson, B. S., Isacsson, S.-O. and Östergren, P.-O., 1992. 'Job strain and mortality in elderly men: social network, support, and influence as buffers', American Journal of Public Health 82, 11361139.

Forbes, J. B. and McGregor, A., 1984. 'Unemployment and mortality in post-war Scotland', Journal of Health Economics 2, 239-257.

Freeman, D. G., 1999. 'A note on [Ruhm's] 'Economic conditions and alcohol problems', Journal of Health Economics 18, 661-670.

Galloway, P. R., 1988. 'Basic patterns in annual variations in fertility, nuptiality, mortality, and prices in pre-industrial Europe', Population Studies 42(2), 275-302.

Gardner, M. J., 1973. 'Using the environment to explain and predict mortality', Journal of the Royal Statistical Society A 136(Part 3), 421-440.

Gavrilova, N. S., Semyonova, V. G., Evdokushkina, G. N., Gavrilov, L. and Ivanova A. E., 2003. 'Recent mortality trends in Russia - Differences between younger and older generations', Paper presented at the 2003 Annual Meeting of the Population Association of America, May 1-3, 2003, Minneapolis.

Gerdtham, U.-G. and Johannesson, J., 2005. 'Business cycles and mortality: results from Swedish microdata', Social Science \& Medicine 60, 205-218.

Gerdtham, U.-G. and Ruhm, C., 2002. 'Death rise in good economic times: evidence from the OECD', NBER Working Paper Series (No. 9357). Cambridge, MA: NBER.

Goff, B. L., 1980. 'Health and the economy: exogenous versus choice variables', Kyklos 43, 437-484.

Graertz, B., 1993. 'Health consequences of employment and unemployment: longitudinal evidence for young men and women', Social Science \& Medicine 36(6), 715-724.

Graham, G., Chang, B. and Evans, J., 1992. 'Poorer is riskier', Risk Analysis 12, 333-337.

Gravelle, H. S. E., Hutchinson, G. and Stern, J., 1981. 'Mortality and unemployment: a critique of Brenner's time series analysis', Lancet 16, 675-679.

Gujarati, D. N., 1995. Basic Econometrics, $3^{\text {rd }}$ ed. McGraw-Hill, New York.

HEI.., 2001. Particulate Air Pollution and Daily Mortality: Analyses of the Effects of Weather and Multiple Air Pollutants - The Phase I.B Report of the Particle Epidemiology Evaluation Project. Health Effects Institute, Cambridge, MA 26.

Hexter, M. B., 1925. Social Consequences of Business Cycles. Hougton Mifflin, Boston, MA.

Higgs, R., 1979. 'Cycles and trends of mortality in 18 large American cities, 1871-1900', Explorations in Economic History 16, 381-408.

Hobson, J. A., 1914. Work and Wealth: A Human Valuation. Macmillan, London.

Hunt, S. M., 1989. 'The public health implications of private cars', in C. J. Martin and D. V. McQueen (eds), Readings for a New Public Health. Edinburgh: Edinburgh University Press, 100-115.

Jäntti, M., Martikainen, P. and Valkonen, T., 2000. 'When the welfare state works: unemployment and mortality in Finland', in G. A. Cornia and R. Paniccià (eds), The Mortality Crisis in Transitional Economies. New York: Oxford University Press, 351-369.

Jin, R. L., Shah, C. P. and Svovoda, T. J., 1995. 'The impact of unemployment on health: a review of the evidence', Canadian Medical Association Journal 153, 529-540.

Johnson, J. and Hall, E. M., 1995. 'Class, work, and health', in B. C. Amick, S. Levine, A. R. Tarlov and D. C. Walsh (eds), Society and Health. New York: Oxford University Press, 247-271.

Junankar, P. N., 1991. 'Unemployment and mortality in England and Wales: a preliminary analysis', Oxford Economic Papers 43, 305-320.

Kagan, A. R., 1987. 'Unemployment causes ill health: the wrong track', Social Science \& Medicine 25, 217-218.

Kacapyr, E., 1996. Economic Forecasting - The State of the Art. M.E. Sharpe, Armonk, NY.

Kalimo, R., El-Batawi, M. A. and Cooper, C. L., 1987. Psychosocial Factors at Work and their Relation to Health. World Health Organization, Geneva.

Kasl, S., 1979. 'Mortality and the business cycle: some questions about research strategies when utilizing macro-social and ecological data', American Journal of Public Health 69, 784-789.

Kasl, S. V. and Wells, J. A., 1985. 'Social support and health in the middle years: work and the family', in S. Cohen and S. L. Syme (eds), Social Support and Health. Orlando, FL: Academic Press, 175-198.

Kiecolt-Glaser, J. K., McGuire, L., Robles, T. F. and Glaser, R., 2002. 'Emotions, morbidity, and mortality - New perspectives from psychoneuroimmunology', Annual Review of Psychology 53, $83-107$. 
Kossoris, M. D., 1938. 'Industrial injuries and the business cycle', Monthly Labor Review 46, 579-575. Koutsoyiannis, A., 1977. Theory of Econometrics, $2^{\text {nd }}$ ed. Barnes \& Noble, Totowa, NJ.

LaPlante, M. P., 1985. Mortality and the Business Cycle. PhD dissertation, Stanford, CA: Department of Sociology, Stanford University.

Laporte, A., 2004. 'Do economic cycles have a permanent effect on population health? Revisiting the Brenner hypothesis', Health Economics 13, 767-779.

Lee, R. D., 1997. 'Population dynamics - Equilibrium, disequilibrium, and consequences of fluctuations', in M. R. Rosenzweig and O. Stark (eds), Handbook of Population Economics. (Vol. 1B). Amsterdam: Elsevier, 1063-1116.

Lew, E. A., 1979. 'Mortality and the business cycle: how far can we push an association?', American Journal of Public Health 69, 782-783.

Lundberg, U. and Hellström, B., 2000. 'Workload and morning salivary cortisol in women', Work \& Stress 16(4), 356-363.

Marmot, M. and Feeney, A., 1996. 'Work and health: implications for individual and society', in A. Blane, E. Brunner and R. Wilkinson (eds), Health and Social Organization - Towards a Health Policy for the $21^{\text {st }}$ Century. London: Routledge, 235-254.

Martikainen, P. T. and Valkonen, T., 1996a. 'Excess mortality of unemployed men and women during a period of rapidly increasing unemployment', Lancet 348, 909-914.

Martikainen, P. T. and Valkonen, T., 1996b. 'The effects of differential unemployment rate increases of occupation groups on changes in mortality', American Journal of Public Health 88, 1859-1861.

Mason, A., 1997. 'The response of fertility and mortality to economic crisis and structural adjustment policy during the 1980s - a review', in G. Tapinos, A. Mason and J. Bravo (eds), Demographic Responses to Economic Adjustment in Latin America. Oxford: Clarendon Press, 17-33.

Mathers, C. D. and Schofield, D. J., 1998. 'The health consequences of unemployment: the evidence', Medical Journal of Australia 168, 178-182.

McAvinchey, I. D., 1984. 'Economic factors and mortality: some aspects of the Scottish case 1950-1978', Scottish Journal of Political Economy 31, 1-27.

McKee, M., 2001. 'The health consequences of the collapse of the Soviet Union', in D. A. Leon and G. Walt (eds), Poverty, Inequality, and Health - An International Perspective. New York: Oxford University Press, 17-36.

Monahan, J. and Vaux, A., 1980. 'Task force report: the macroenvironment and community mental health', Community Mental Health Journal 16, 14-26.

Neumayer, E., 2004a. 'Recessions lower (some) mortality rates: evidence from Germany', Social Science \& Medicine 58, 1037-1047.

Neumayer, E., 2004b. 'Erratum corrigendum. Recessions lower (some) mortality rates: evidence from Germany', Social Science \& Medicine 59, 1993.

NSF, National Safety Council, 1991. Accident Facts - 1991 Edition. Chicago, IL: NSF.

Ogburn, W. F. and Thomas, D. S., 1922. 'The influence of the business cycle on certain social conditions', Journal of the American Statistical Association 18, 324-340.

Ortega-Osona, J. A. and Reher, D., 1997. 'Short-term economic fluctuations and demographic behavior: some examples from $20^{\text {th }}$ century South America', in G. Tapinos, A. Mason and J. Bravo (eds), Demographic Responses to Economic Adjustment in Latin America. Oxford: Clarendon Press, 129-155.

Palloni, A. and Hill, K., 1997. 'The effects of economic changes on mortality by age and cause: Latin America 1950-90', in G. Tapinos, A. Mason and J. Bravo (eds), Demographic Responses to Economic Adjustment in Latin America. Oxford: Clarendon Press, 75-128.

Peterson, C. L., 1994. 'Work factors and stress: a critical review', International Journal of Health Services 24, 495-519.

Phillips, D. P., Christenfeld, N. and Ryan, N. M., 1999. 'An increase in the number of deaths in the US in the first week of the month', New England Journal of Medicine 341, 93-98.

Rios-Neto, E. and Carvalho, J. A. M., 1997. 'Demographic consequences of structural adjustment: the case of Brazil', in G. Tapinos, A. Mason and J. Bravo (eds), Demographic Responses to Economic Adjustment in Latin America. Oxford: Clarendon Press, 174-198.

Robertson, C. and Ecob, R., 1999. 'Simultaneous modeling of time trends and regional variation in mortality rates', International Journal of Epidemiology 28, 955-963. 
Robinson, J. C., 1988. 'The rising long-term trend in occupational injury rates', American Journal of Public Health 78, 2676-2681.

Robinson, J. C. and Shor, G. M., 1989. 'Business-cycle influences on work-related disability in construction and manufacturing', Milbank Quarterly 67(Suppl. 2, Pt. 1), 92-113.

Ruhm, C. J., 1995. 'Economic conditions and alcohol problems', Journal of Health Economics 14, 583-603.

Ruhm, C. J., 2000. 'Are recessions good for your health?' Quarterly Journal of Economics 115, 617-650.

Ruhm, C. J., 2003. 'Good times make you sick', Journal of Health Economics 22, 637-658.

Ruhm, C. J., 2004. 'Macroeconomic conditions, health and mortality', NBER Working Paper 11007. Cambridge, MA: National Bureau of Economic Research.

Sáez, A., 1975. Población y actividad económica en España. Siglo XXI, Madrid.

Schnall, P., Belkić, K., Landsbergis, P. and Baker, D. (eds), 2000. 'The workplace and cardiovascular disease', Occupational Medicine: State of the Art Reviews 15(1): 1-162; 307-322.

Schofield, R., 1983. 'The impact of scarcity and plenty on population change in England, 1547-1871', in R. I. Rotberg and T. K. Rabb (eds), Hunger and History - The Impact of Changing Food Production and Consumption Patterns on Society. Cambridge: Cambridge University Press, 67-94.

Seeman, T. E. and Berkman, L. F., 1988. 'Structural characteristics of social networks and their relationship with social support in the elderly: who provides support', Social Science \& Medicine 26(7), $737-749$.

Sokejima, S. and Kagamimori, S., 1998. 'Working hours as a risk factor for acute myocardial infarction in Japan: a case-control study', British Medical Journal 317, 775-780.

Søgaard, J., 1992. 'Econometric critique of the economic change model of mortality', Social Science \& Medicine 34, 947-957.

Sparks, K., Cooper, C., Fried, Y. and Shirom, A., 1997. 'The effects of hours of work on health: a metaanalytic review', Journal of Occupational \& Organizational Psychology 70, 391-408.

Spiegel, K., Leproult, R. and Van Cauter, E., 1999. 'Impact of sleep debt on metabolic and endocrine function', Lancet 354, 1435-1439.

Steenland, K. 1996. 'Epidemiology of occupation and coronary heart disease: research agenda'. American Journal of Industrial Medicine 30, 495-499.

Sterling, P. and Eyer, J., 1981. 'Biological basis of stress-related mortality', Social Science \& Medicine 15E, 3-42.

Stern, J., 1983. 'The relationship between unemployment, morbidity and mortality in Britain', Population Studies 37, 61-74

Tapia Granados, J. A., 1994. 'Accidentes de trabajo en España: comentarios a propósito del trabajo de Moncada y Artazcoz', Cuadern CAPS (Barcelona) 20, 57-60.

Tapia Granados, J. A., 2002. Mortality and Economic Fluctuations - Theories and Empirical Results from Spain and Sweden. PhD Dissertation. New York: Graduate Faculty of Political and Social Science, New School University.

Tapia Granados, J. A., 2004. 'Mortality and economic fluctuations in Sweden, 1800-1998', Paper presented at the 2004 Meeting of the Population Association of America, Boston, MA, April 2004.

Tapia Granados, J. A., 2005. 'Increasing mortality during the expansions of the U.S. economy, 1900-1997', International Journal of Epidemiology (accepted for publication). Available at http:// ije.oxfordjournals.org/cgi/content/abstract/dyil41v1.

Tapinos G., Mason, A. and Bravo, J. (eds), 1997. Demographic Responses to Economic Adjustment in Latin America. Oxford: Clarendon Press.

Thomas, D. S., 1925. Social Aspects of the Business Cycle. Routledge, London.

Thomas, D. S., 1941. Social and Economic Aspects of Swedish Population Movements 1750-1993. Macmillan, New York.

Valkonen, T. and Martikainen, P., 1995. 'The association between unemployment and mortality: causation or selection?' in A. D. Lopez, G. Caselli and T. Valkonen (eds), Adult Mortality in Developed Countries: From Description to Explanation. Oxford: Clarendon Press, 201-222.

Wagstaff, A., 1985. 'Time series analysis of the relationship between unemployment and mortality: a survey of econometric critiques and replications of Brenner's studies', Social Science \& Medicine 21, 985-996.

Walsh, M. W., 2000. 'As hot economy pushes up overtime, fatigue becomes a labor issue', The New York Times, Sept. 17, 32. 
Watkins, S., 1985. 'Recession and health: a literature review', in G. Wescott, P.-G. Svensson and H. F. K. Zölner (eds), Health Policy Implications of Unemployment. Copenhagen: World Health Organization Regional Office for Europe.

WHO., 1992. Our Planet, Our Health: Report of the WHO Commission on Health and the Environment. World Health Organization, Geneve.

Winter, J., 1983. 'Unemployment, nutrition and infant mortality in Britain, 1920-50', in J. Winter (ed), The Working Class in Modern British History: Essays in Honour of Henry Pelling. Cambridge: Cambridge University Press, 232-256.

Zeger, S. L., Dominici, F. and Samet, J. 1999. 'Harvesting: Resistant estimates of air pollution effects on mortality'. Epidemiology 10, 171-175. 